\title{
原 著 \\ ハイリスク新生児を出産した母親の \\ 自立過程に関する一考察 \\ The Process of Establishment of Maternal Confidence after the Delivery of High-Risk Infant
}

\author{
宮 中 文子(Fumiko MIYANAKA)* 宮 里 和 子(Kazuko MIYASATO)**
}

八イリスク新生児を出産した母親の自立過程は, 出産後の危機から立ち直り, 児のリスクを受け入れ, 育児に自信がもて，母性性が発達していく過程であるといえる。新生児集中治療室に入院した児をもつ 母親77名について，母親の自立過程に影響を及ほす要因を分析した結果, 自立を促す要因は, 入院期間 が 1 か月未満, 新生児が低出生体重児ではない, 母親が退院時や退院後に心配・不安がない, 退院時に 児の看護上の問題がないなどであり，その要因が欠けている者では自立が遅れる傾向がみられた。

また類似した要因をもちながら, 自立の時期の異なる事例の比較では, 早期に児の状況に直面し, 不 安感情を表出し, 児との関係を回復し, 社会的支援を受けている者などでは育児に自信がもて, 自立が 早かった。これらのことから，ハイリスク新生児を出産した母親に対しては，自立を促す要因を助長す るようバランス保持を図るなど，両親の親としての意識と役割の発達を促す支援システムが望まれる。

\section{Abstract}

It can be considered that maternal confidence after the delivery of high-risk infant is acquired through recovering from crisis after the delivery, accepting the handicapped conditions of the infant, gaining self-reliance in child-care, and developing the maternity.

In this report we examined the factors influencing the establishment of maternal confidence after the delivery of high-risk infant.

The sample was composed of 77 mothers whose infants were hospitalized in the NICU.

The result of this study was as follows;

1. It was proved that maternal confidence was influenced by four factors; hospitalization for less than one month, no lowbirth weight infant, no anxiety after discharge, and no problem on nursing care.

2. Maternal confidence to delay in short of the above factors.

3. The periods required for maternal confidence were different among mothers with high-risk infants in spite of similarity of their factors. Mothers, that is, who cognized the handicapped

*京都府立医科大学附属看謨専門学校助産学科 (Midwifery Course, Nursing School Attached Kyoto Prefectural University of Medicine)

**国立公綠衛生院公衆衛生看護学部（Department of Public Health Nursing, Institute of Public Health) 
conditions of their infants, expressed the feeling of anxiety, moderated the relationship with their infants, and were provided with available social support at an earlier stage, could be independent earlier.

We think it is important to provide the mothers with social support at an earlier stage on account of developing maternal confidence after delivery of high-risk infant.

\section{I 緒言}

ハイリスク新生児の出産は，母親にとってスト レスであり，心理的危機状態に陥りやすいといわ れる。アギュララ等1) は危機発生と回避のモデル を示し，均衡を回復させるバランス保持要因があ るかないかによって危機を促進させたり，危機か ら回避できたりするとしている。また，カプラン $(\text { Kaplan })^{2)}$ は末熟児を出産した母親ではストレ スにうまく对応するため，適切な時期に各課題を やり遂げねばならないと述べている。クラウス 等 ${ }^{3)}$ は，母子分離をすることにより，母子相互作用 が阻害され母子関係や児の発達に影響を来しやす いとしている。ハイリスク新生児の発達と母親の 心理や行動との関連については，これまでにも調 查が行われ, 出生直後からの母子相互作用が助長 されるような援助が重要であることが報告されて いる(15)6)。

一方，母性とは子との相互作用の過程で漸次確 立されていくといわれているが，ゴールドバー グ7は，児の個性（状態）が母親の有能感（自信） に影響しており，適応力の限られた乳児の親では 相互作用の失敗する危険度が潜在的に高いと報告 している。

しかし，母親がリスクをもつ児との関係を成立 させ自立していく過程についてはまだ明らかでは ない。本論文におけるハイリスク新生児を出産し た母親の「自立」とは，母親がリスクをもつ児を 受け入れ，育児に自信がもて，育児に伴って生じ る心配や不安に対してそれなりに対処できること をいう。その過程で自立を促す要因を明らかにし， 自立の時期に差があった者を中心に事例検討を行 い, ハイリスク新生児を出産した母親の自立を促 す援助について考虑した。

\section{1) 研究目的}

未熟児・疾患や障害をもつ児の母親について， 児のリスクを受け入れ，育児に自立してゆく要因
と心理的過程を知り，看護者の援助のあり方を考 之る。

\section{2 ) 用語の定籍}

ハイリスク新生児：疾患をもつ児，未熟児，八 イリスク妊婦から生まれた児などで，何らかの処 置や十分な観察が必要な新生児。

自立：育児行動を含むセルフケアの自立で，母 親が子との関係を成立させ，育児に自信をもつこ とが重要な要素となる。

心配・不安：心配とは，心的負担になる事項で, 不安とは, 漠然とした危険や脅威に対する反応。

\section{II 研究方法}

\section{1. 対 象}

昭和 62 年 1 月から 63 年 3 月までに京都府立医科 大学附属病院周産期䧐療部新生児集中治療室 (NICU)に入院した児157名から，出生直後に入院 した児をもつ母親の全数 100 名を対象とし,うち回 答の得られた77名 $(77 \%)$ である。

\section{2. 調查内容および調查方法}

\section{1) 質問紙調查}

郵送法による質問紙調査を行い，以下の項目に ついて想起させ回答を得た。(1)母親の心理的推移 と専門家や家族の支援に関する項目として, 初回 面会時の心理, 児の病状説明に対する理解, 退院 時の児に対する心配・不安, 退院後の家庭保育で の心配・不安, 入院中および退院後の支㩖状況, 育児に対する自信を得たきっかけ。(2)保健指導と 母親の行動に関する項目として初回面会の時期, 面会頻度, 育児参加状況, 退院指導, 母乳哺育の 状況である。

2）面接または電話訪問による追加調查

アンケート調査の時点で育児にまだ自信のなか つた者 9 名について，その後 5 か月までに行い, 自信のついた時期あるいはつかない理由について 回答を得た。

3 ) 既存資料による調查 
以下の資料から，母児の属性に

表 1-1 対象者の属性

関する項目として母親の年齿, 家 族形態, 育坚経験, 出生施設, 通 院距離，母親の合併症，児の入院 日数, 児の病名, 母児の看護上の 問題と指導について調査した。ま た母親の心理的推移についての情 報を収集し，アンケート調査の回 答内容との照合を行った。

(1)看護サマリー（継続看護依頼 用紙)。

(2)面会記録：児に関する看護婦 と両親との交換記録で，母親の心 理的推移を知るだけでなく母子関 係確立にも役立っている ${ }^{8)}$ 。

(3)新生児訪問返信記録。

\section{3. 分析方法}

自立に影響すると考えられる要 因の 21 項目について，早期自立群と晚期自立群の 比率に差があるかを検討し，そのうえで，類似し た要因をもちながら自立の時期に差のあった事例 を中心に検討した。ここでは母親の自立というこ とを「母親が児のリスクを受け入れ，育児に自信 がもて，心配・不安に対し対処できること」と考 えた。具体的には「赤ちゃんの育て方がわかり， なんとか育てていけると思われた」時期を児の生 後の月数で答えてもらい，その時点で母親が自立 できたものとした。早い時期に自立した者は，自 立が遅れた者に比べて自立を促す要因を多くもっ ていたものと考え，4 か月未満に自立した早期自 立群と 4 か月以後であった晚期自立群に分けた。 生後 4 か月で区分したのは，危機の持続は $4 \sim 6$ 週といわれているが，この場合，危機回避し育児 に自信がつくのは母親が自分で育児する退院後で あるという結果から，4 か月で区分した。なお調 查終了時点でまだ自信がないと答えたものは晚期 自立群に含めた。

\section{4. 調查施設の NICU のケアについて}

児に対する「後障害なき救命」を目的とした治 療的ケアが主であるが，両親に対しては親子関係 成立への援助，育児自立への援助を行っている。 その内容は, 両親の早期面会, 児との接触, 面会 ノ一ト, 育児参加, 母乳哺育, 退院指導, 地域保
表 1 - 2 対象児の属性

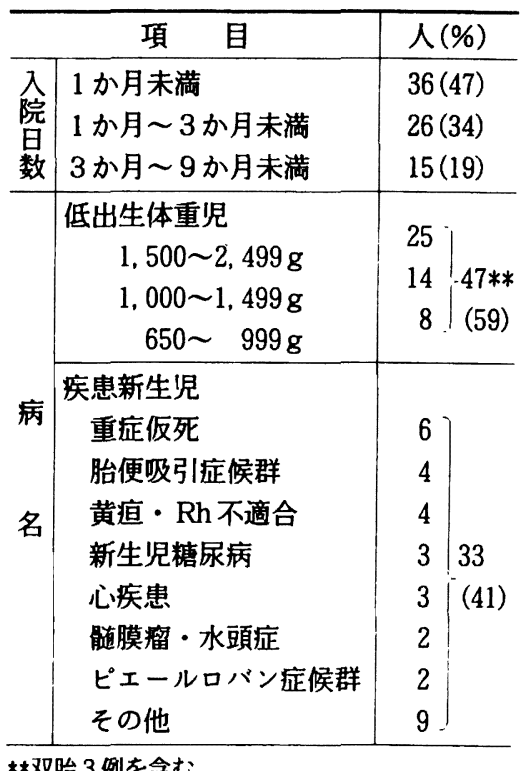

健婦との継続看護などである。

\section{III 結 果}

\section{1. ハイリスク新生児を出産した母親の自立の時} 期と支れに関する要因

1 ）対象者の背景は表 1 に示すとおりである。

調查時点での, 児の年秢は生後 5 か月から 1 歳 8 か月であった（表 1)。

2 ) 母親の自立の時期とそのきっかけ

「育児に自信がついた」時期は，生後 1 か月から 12か月以上と個人差が大きかった。自信がついた 理由は, 早期自立群では「体重増加」や「定頸」 などの発育や発達が確認できたことが最も多く， ついで生活リズムや授乳の確立などの予測しやす さ，私を見て笑うなどの読み取りやすさをあげた 者が多くみられた。晚期自立群でも発育や発達の 確認が多かったが，次いで，児の読み取りやすさ をあげた者が多かった。母体の健康回復と答えた 者は晚期自立群のみに，育児経験あるためと答え た者は早期自立群のみにみられた（図 1，表 2)。 3 ）母親の早期自立に関連する要因

早期に自立した者が有意に多かった項目は，属 性項目では児の入院日数が 1 か月未満の者, 低出 生体重児に比べ疾病新生児, 保健指導と母親行動 では退院時に児の看護上の問題のなかった者, 退 


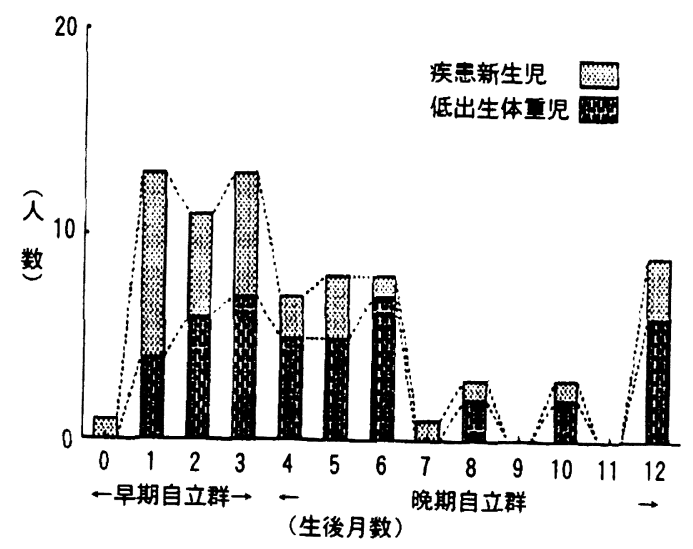

図1育児に自信が得られた時期

表 2 育児に自信がついた理由

(早期自立群38名、晚期自立群39名の内訳)

\begin{tabular}{|c|c|c|c|}
\hline 項 目 & 内 & \begin{tabular}{|lr} 
早 期 \\
自立群
\end{tabular} & $\begin{array}{l}\text { 晚 期 } \\
\text { 自立群 }\end{array}$ \\
\hline $\begin{array}{l}\text { 児の発育 } \\
\text { や発達の } \\
\text { 確認 }\end{array}$ & $\begin{array}{l}\text { 定頚、体重増加 } \\
\text { 検診時順調といわれ } \\
\text { 要返り・お座りができた } \\
\text { 健常児に追いついた }\end{array}$ & 10 & 13 \\
\hline $\begin{array}{l}\text { 児の予測 } \\
\text { しやすさ }\end{array}$ & $\begin{array}{l}\text { 生活リズムができた } \\
\text { 夜中眠る, 夜泣きなくなる } \\
\text { 母乳をよく饮む } \\
\text { 授乳の確立 }\end{array}$ & 10 & 5 \\
\hline $\begin{array}{l}\text { 児の読み } \\
\text { 取りやす } \\
\text { さ }\end{array}$ & $\begin{array}{l}\text { 私を見て笑う, 人に反応 } \\
\text { 私が抱くと泣きやむ } \\
\text { 赤ちゃんの要求がわかる } \\
\text { 親のいうことがわかる }\end{array}$ & 6 & 8 \\
\hline $\begin{array}{l}\text { 児の隨害 } \\
\text { の回復 }\end{array}$ & $\begin{array}{l}\text { 訓練の成果あり } \\
\text { 障害は軽いといわれて } \\
\text { ロからミルクが飲めた }\end{array}$ & 2 & 3 \\
\hline $\begin{array}{l}\text { 母体の健 } \\
\text { 康回復 }\end{array}$ & $\begin{array}{l}\text { 好娠中毒症が治って } \\
\text { 乳腺炎が治って }\end{array}$ & 0 & 2 \\
\hline 育児経験 & $\begin{array}{l}\text { 育児経験あり } \\
\text { 実家から自宅に帰って }\end{array}$ & 4 & 1 \\
\hline
\end{tabular}

(まだ自信がないと答えた者 6 名を除く重複回答)

院指導を受けなかったと答えた者であった。ただ し退院指導は実際には医師と看護婦により全員に 行われている。心理的推移と支援では, 退院時や 退院後に心配・不安のなかった者, 入院中に心理 的支援を看護婦から受けなかったと答えた者であ つた。入院中の支援者は看護婦，新生児 (面会)， 医師の順に多く, 退院後は実母, 夫, 保健婦の順
表 3 各属性項目と育児自立の時期との関連

\begin{tabular}{|c|c|c|c|c|}
\hline 項 & 目 & $\begin{array}{l}\text { 早 期 } \\
\text { 自立群 }\end{array}$ & $\begin{array}{l}\text { 晚 期 } \\
\text { 自立群 }\end{array}$ & 小計 \\
\hline & $\begin{array}{l}\text { 30歳未満 } \\
30 \text { 歳以上 }\end{array}$ & $\begin{array}{l}18(46) \\
20(53)\end{array}$ & $\begin{array}{l}21(54) \\
18(46)\end{array}$ & $\begin{array}{l}39(100) \\
38(100)\end{array}$ \\
\hline 家族形態 & & $\begin{array}{r}33(50) \\
5(45) \\
\end{array}$ & $\begin{array}{r}33(50) \\
6(55)\end{array}$ & $\begin{array}{l}66(100) \\
11(100)\end{array}$ \\
\hline 育児経験 & $\begin{array}{l}\text { あり } \\
\text { なし }\end{array}$ & $\begin{array}{l}22(56) \\
16(42)\end{array}$ & $\begin{array}{l}17(44) \\
22(58)\end{array}$ & $\begin{array}{l}39(100) \\
38(100)\end{array}$ \\
\hline 出生施設 & \begin{tabular}{|l|} 
院内 \\
院外
\end{tabular} & $\begin{array}{l}21(46)^{c} \\
17(55)\end{array}$ & $\begin{array}{l}25(54)^{d} \\
14(45)\end{array}$ & $\begin{array}{l}46(100) \\
31(100)\end{array}$ \\
\hline 通院距離 & $\begin{array}{l}\text { 市内 } \\
\text { 市外 }\end{array}$ & $\begin{array}{l}22(44) \\
16(59)\end{array}$ & $\begin{array}{l}28(54) \\
11(41)\end{array}$ & $\begin{array}{l}50(100) \\
27(100)\end{array}$ \\
\hline $\begin{array}{l}\text { 母親の合 } \\
\text { 併症 }\end{array}$ & $\begin{array}{l}\text { なし } \\
\text { あり }\end{array}$ & $\begin{array}{l}24(52) \\
14(45)\end{array}$ & $\begin{array}{l}22(48) \\
17(55) \\
\end{array}$ & $\begin{array}{l}46(100) \\
31(100)\end{array}$ \\
\hline $\begin{array}{l}\text { 児の入院 } \\
\text { 日数 }\end{array}$ & $\begin{array}{l}1 \text { か月未満 } \\
1 \text { か月以上 }\end{array}$ & $\begin{array}{l}27(75) \\
11(27)\end{array}$ & $\begin{array}{r}9(25) \\
30(73)\end{array}$ & $\begin{array}{l}36(100) \\
41(100)\end{array}$ \\
\hline 児の病名 & \begin{tabular}{|l|} 
宛患新生児 \\
低出生体重児
\end{tabular} & $\begin{array}{l}21(64) \\
17(39)\end{array}$ & $\begin{array}{l}12(36) \\
27(61)\end{array}$ & $\begin{array}{l}33(100) \\
44(100)\end{array}$ \\
\hline
\end{tabular}

** $\mathrm{p}<0.01 \quad * \mathrm{p}<0.05 \quad$ (c 13名 d 18名 母体搬送を含む)

\section{表 4 保健指道や母親行動之育児自立の時期} との関連

\begin{tabular}{|c|c|c|c|c|}
\hline 項 & 目 & $\begin{array}{ll}\text { 早 } & \text { 期 } \\
\text { 自立群 }\end{array}$ & \begin{tabular}{|l|} 
晚 期 \\
自立群
\end{tabular} & 小計 \\
\hline \multirow{2}{*}{$\begin{array}{l}\text { 初回面会時 } \\
\text { 期 }\end{array}$} & 7 日未満 & $31(53)$ & $27(47)$ & $58(100)$ \\
\hline & 7 日り & $7(37)$ & $12(63)$ & $19(100)$ \\
\hline \multirow{2}{*}{ 面会頻度 } & 毎日 & $28(50)$ & $28(50)$ & $56(100)$ \\
\hline & 週 $1 \sim 3$ 日 & $10(48)$ & $11(52)$ & $21(100)$ \\
\hline \multirow{2}{*}{ 育児参加 } & できた & $35(49)$ & $37(51)$ & $72(100)$ \\
\hline & できない & $3(60)$ & $2(40)$ & $5(100)$ \\
\hline \multirow{2}{*}{$\begin{array}{l}\text { 児の看讙上 * } \\
\text { の問題 }\end{array}$} & なし & $20(67)$ & $10(33)$ & $30(100)$ \\
\hline & あり & $18(38)$ & $29(78)$ & $47(100)$ \\
\hline \multirow{2}{*}{$\begin{array}{l}\text { 母親の看護 } \\
\text { 上の問題 }\end{array}$} & なし & $13(52)$ & $12(48)$ & $25(100)$ \\
\hline & あり & $25(48)$ & $27(52)$ & $52(100)$ \\
\hline \multirow{2}{*}{ 退院指導 } & 受けた & $31(45)$ & $38(55)$ & $69(100)$ \\
\hline & 受けない & $7(88)$ & $1(12)$ & $8(100)$ \\
\hline \multirow{2}{*}{ 母乳哺育 } & 確立 & $18(43)$ & $24(57)$ & $42(100)$ \\
\hline & 末確立 & $20(57)$ & $15(43)$ & $35(100)$ \\
\hline
\end{tabular}

$* \mathrm{p}<0.05$

であった。有意差はないが，早期に自立した者が 多い傾向が見られた項目は，母親の年秢が30歳以 上の者, 育児経験のある者, 通院時点の住所が市 外の者, 母親の合併症のなかった者, 初回面会時 に否定感情を表現した者であった。 
表 5 心理的推移や支援と育児自立の時期との 関連

\begin{tabular}{|c|c|c|c|c|c|}
\hline \multirow{2}{*}{\multicolumn{2}{|c|}{$\frac{\text { 項 }}{\text { 児の病状の }}$}} & 目 & $\begin{array}{l}\text { 早期 } \\
\text { 自立群 }\end{array}$ & $\begin{array}{l}\text { 晚 期 } \\
\text { 自立群 }\end{array}$ & 小計 \\
\hline & & $\begin{array}{l}\text { している } \\
\text { してない }\end{array}$ & $\begin{array}{r}35(52) \\
3(30)\end{array}$ & $\begin{array}{r}32(48) \\
7(70)\end{array}$ & $\begin{array}{l}67(100) \\
10(100)\end{array}$ \\
\hline \multicolumn{2}{|c|}{$\begin{array}{l}\text { 初回面会時 } \\
\text { の心理 }\end{array}$} & $\begin{array}{l}\text { 肯定・両価 } \\
\text { 否定 }\end{array}$ & $\begin{array}{l}15(43) \\
23(55)\end{array}$ & $\begin{array}{l}20(57) \\
19(45)\end{array}$ & $\begin{array}{l}35(100) \\
42(100)\end{array}$ \\
\hline \multicolumn{2}{|c|}{$\begin{array}{l}\text { 退院時の心 } \\
\text { 配・不安 }\end{array}$} & $\begin{array}{l}\text { なし } \\
\text { あり }\end{array}$ & $\begin{array}{l}13(81) \\
25(41)\end{array}$ & $\begin{array}{r}3(19) \\
36(59)\end{array}$ & $\begin{array}{l}16(100) \\
61(100)\end{array}$ \\
\hline \multicolumn{2}{|c|}{$\begin{array}{l}\text { 退院後の心 } \\
\text { 配・不安 }^{* *}\end{array}$} & & & & \\
\hline \multirow{2}{*}{$\begin{array}{l}\text { 入 } \\
\text { 院 } \\
\text { 中 }\end{array}$} & 看護婦" & $\begin{array}{l}\text { あり } \\
\text { なし }\end{array}$ & $\begin{array}{l}23(42) \\
15(68)\end{array}$ & $\begin{array}{r}32(58) \\
7(32)\end{array}$ & $\begin{array}{l}55(100) \\
22(100)\end{array}$ \\
\hline & 新生児 & $\begin{array}{l}\text { あり } \\
\text { なし }\end{array}$ & $\begin{array}{l}23(43) \\
15(63)\end{array}$ & $\begin{array}{r}30(57) \\
9(38)\end{array}$ & $\begin{array}{l}53(100) \\
24(100)\end{array}$ \\
\hline \multirow{2}{*}{ 援 } & 医師 & $\begin{array}{l}\text { あり } \\
\text { なし }\end{array}$ & $\begin{array}{l}25(49) \\
13(50)\end{array}$ & $\begin{array}{l}26(51) \\
13(50)\end{array}$ & $\begin{array}{l}51(100) \\
26(100)\end{array}$ \\
\hline & 夫 & $\begin{array}{l}\text { あり } \\
\text { なし }\end{array}$ & $\begin{array}{l}20(43) \\
18(60)\end{array}$ & $\begin{array}{l}27(57) \\
12(40)\end{array}$ & $\begin{array}{l}47(100) \\
30(100)\end{array}$ \\
\hline 退 & 実母 & $\begin{array}{l}\text { あり } \\
\text { なし }\end{array}$ & $\begin{array}{l}22(50) \\
16(48)\end{array}$ & $\begin{array}{l}22(50) \\
17(52)\end{array}$ & $\begin{array}{l}44(100) \\
33(100)\end{array}$ \\
\hline $\begin{array}{l}\text { 後 } \\
\text { の }\end{array}$ & 夫 & $\begin{array}{l}\text { あり } \\
\text { なし }\end{array}$ & $\begin{array}{l}20(50) \\
18(49)\end{array}$ & $\begin{array}{l}20(50) \\
19(51)\end{array}$ & $\begin{array}{l}40(100) \\
37(100)\end{array}$ \\
\hline 发 & 保健婦 & $\begin{array}{l}\text { あり } \\
\text { なし }\end{array}$ & $\begin{array}{l}15(52) \\
23(48)\end{array}$ & $\begin{array}{l}14(48) \\
24(52)\end{array}$ & $\begin{array}{l}29(100) \\
48(100)\end{array}$ \\
\hline
\end{tabular}

$* * \mathrm{p}<0.01 * \mathrm{p}<0.05$

逆に自立が遅れた者が多い傾向があった項目 は, 児の入院初期の病状について説明を受けたが 理解できなかった者, 初回面会が 7 日以後と遅れ た者，母乳哺育未確立の者であった。

退院後の相談相手による差異はほとんどなかっ た。ただし，支援者の平均数では，入院中は，早 期群が 3.8 人に比較し, 晚期群が 4.3 人と多く, 退 院後でもやや晚期群に多かった（表 3, 表 4, 表 5 )。

\section{2. 專例検討}

類似した要因をもちながら, 育児に対する自信 の時期が早い事例と遅れた事例について比較検討 した。

\section{1）仮死児の母親 2 事例の比較（図 2 ）}

事例はいずれも重症仮死児で, 神経学的予後が 要注意の児をもつ初産婦である。いずれも他院出
産で吸引分娩しており, 新生児のみが本学に入院 となっている。C事例は，児が仮死になり入院と なったことを正しく知っていて，初回面会時には 「やっと会えて胸がジーンときた。すぐ抱いてや りたかった」と答えている。退院後すぐに訓練施 設での入院訓練を行っている。退院後早期の生後 2 か月に自信がついたが, そのきっかけは, 「退院 時にできなかったおっぱいが飲めるようになり， この子なりにゆっくり成長していることがわかっ たから」と答えている。

一方, $\mathrm{D}$ 事例は里帰り分婏で, 児は低酸素性脳 症にて入院している。母親は「強い貧血があるた め外出が許可されず，児の状態や入院の説明はな かった」と答えている。NICUに入院後，父親に 対し児の状態についての説明をしている。母親は， 生後 8 日に初回の面会をしており，このとき，児 は急性期を脱していたが，その状態を見て，「元気 に生んでいたらこんな目にあわなくてよかったの に，申し訳ない」と自責の気持ちが強く，「順調に 育つか, 何か障害が残らないか」と心配している。 母親は育児参加し, 授乳も行っているが, 児が眠 つていることが多く，母乳確立せずに退院し，実 家に帰っている。その後「児がよく吐く」という 訴之が強く，母親への育児指導のため再入院して いる。2 か月後に自宅へ州ったが，夫の転勤のた め転居直後の社宅で，近隣のサポートもなく育児 に孤立している。退院後はNICU 看護者から保健 所保健婦への継続看護の依頼により，保健婦の訪 問指導が実家滞在中 1 回と, 自宅に帰ってからも 数回行われている。しかし，1歳 3 か月の現在も 自信がまだないと答えている。その理由は,「いぎ 家 (実家) に連れて帰ると，入院中に1日1時間 通っていたのではわからないことばかりだった。 ミルクをよく吐き続けるのでどこか悪いところが あるのではと不安でどうにもならず，病院に電話 相談をしたら，赤ちゃんの様子が悪いということ ではなく，お母さんの排気のやり方が悪いのでは ないかといわれた。それから，よその子に比べず つと体重が少ないのも，自分の育て方が悪いので はないかと自信がもてない」と答えている。その 後の追加調査でも自信はないと答えており,「体重 が増えないんです。食べても吐きます」と訴えて いる。その後, 電話訪問を重ね, 1 歳 7 か月時に 


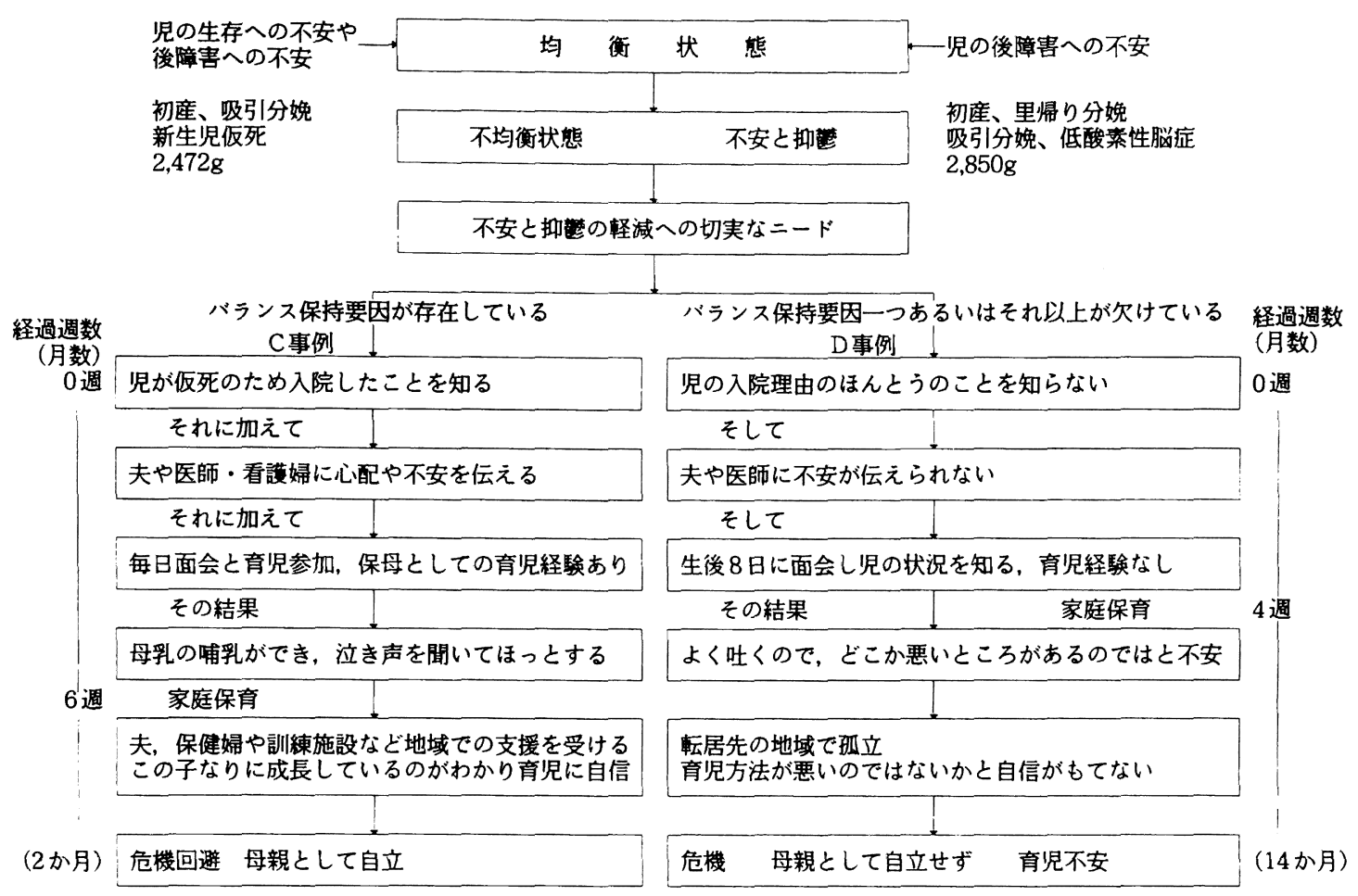

図2重症仮死児の母親 2 事例の比較

は「吐くことは少なくなった，よく歩きます」と 答え，肯定的な表現が聞かれるようになった。

\section{IV 考察}

ハイリスク新生児を出産した母親の自立に関す る要因については，入院期間や退院時の児の問題 など児の病態や予後に関する項目のほか，退院時 や退院後の心配・不安がないなどが当然ではある が大きく影響していた。Caplan ${ }^{9110)}$ は危機 (Crisis) とは一時的に解決できない問題に直面して，適応 と順応に苦しんでいる状態であり，危機は心理的 な弱点の增大する危険と，パーソナリティーが成 長する機会という二面を現す過度的な時期である としている。事例でも危機に陥りやすく，自立の 遅い者と，危機回避し，自立の早い者がみられた。 アギュララ(1)は，バランス保持要因として現実的 知党, 社会的支持, 対処機構などを考虑し, 支援 することにより危機回避できるとしているが，ク ロス集計の結果と事例からもそのことがいえた。

現実的知党では，児の現実を早期に知賞し，不 安感情を表出した者では, 児との関係を回復し育
児に自信を得ている。その結果，早期に危機回避 ができ，自立したと思われた。またその立ち直り の過程は，カプラン(Kaplan) ${ }^{12)}$ の報告した末熟 児を出産した母親の心理過程に相似していた。類 似した要因をもちながら自立時期に相違のある事 例の比較でも，C事例では出産直後から児の状況 に直面し，早期接触により正しく現実を知覚して いるが，D事例では，早期に児の現実は知らされ てなかった。このことから，母親は早期に児と面 会し，現実に直面することが必要と思われた。

次に母親の対処機構については，リスク児では 反応が弱く，相互作用が障害されやすいことが多 い。ゴールドバーグ13)は，児の状態の予測しやす さ, 読み取りやすさが母親の育児有能感につなが るとしている。C事例は保母の経験があったのに 比べ，D事例は初めての育児のうえ，育児参加で は児が眠りがちであり, 効果的な母子相互作用が 行われなかったため，リスクに特有の理解ができ ず児が受容できなかったと考えられる。このこと から, NICUのケアにおいては, 効果的な母子相 互作用ができるようにし，母親が児の状態を読み 
取ったり，予測したりする力を発達できるように し，育児の自信が高められるような支援が必要と 考えた。また，育児指導は児の個性を踏まえて行 う必要があると思われた。

社会的支持については,クロス集計の結果では 支援者の有無と早期自立との関連に有意差はなか つたが，事例では夫や地域での支援が影響してい た。C事例では, 職場のサポートに加え, 訓練施 設でのサポートがあったのに比へ，D事例では, 里帰りや転居により, 地域のサポートが得られに くかったことがある。また, 転院先への紹介状の 持参や，郵送による継続看護依頼は行われたが, 母親にとっては十分な支援とはならなかったと考 えられる。久田 ${ }^{14)}$ 報告でも夫のサポートはスト レスの緩和効果があるとしており，夫や家族の支 援は重要と思われた。しかし, 現在の核家族での 育児機能は弱く，家族もまた危機に陥りやすいた め、母親が家族や地域で孤立化せず，母親と児が 発達してゆけるような支援システムが必要と思わ れる。例之ば, 保健, 医療, 福祉の母子保健にか かわる多くの社会資源のネットワークづくりが試 みられるのも一つの方向といえよう ${ }^{15)}$

母親の心配や不安と母親の自立との関連につい ては, 退院後に育児の心配・不安のある者が多か ったが, 心配とは, 過重すぎず, 個人の対処力の 範囲の問題か, 信頼できる支持がある場合と思わ れ、これは発達に必要な要素ともいえる。また, 不安とは，漠然とした危険や脅威に対する反応で あり，それが強度になった状態が危機と考えられ た ${ }^{16)}$ 。質問紙調査では，心配や不安があっても同時 に育児に自信が得られた人と，自信のない人がい た。育児に自信のない母親は, 周冊の支援や対処 力が弱かったり，自分の育児自信のよりどころと なる根拠がもてない状態であり，自立していない と思われた。一方，自立した者では，早期から訓 練施設で養育指導を受けるなど, 地域の専門家な どの支援が大きく影響していたことから，心配や 不安があっても，それなりに対処しているといえ るのではないかと考えられた。しかし，ハイリス ク新生児を出産した母親は個々人で，危機状況の 受け止めや認識，対処方法も異なるため，それを 考虑して，母親の心配や不安に対する援助を行う 必要があると考えた。
以上のことから，ハイリスク新生児をもつ母親 の自立過程は, 出産後の危機から立ち直り, 児と の関係を回復し，育児に自信がもて，母性として 発達していく過程と考えた。そのため, ハイリス ク新生児を出産した母親に対しては，自立を促す 要因を助長するようバランス保持を図るなど，両 親の親としての意識や役割の発達を促す支援シス テムが望まれる。

\section{$\mathrm{V}$ 結 論}

ハイリスク新生児を出産した母親では危機に陥 りやすく自立過程の遅い者と, 危機回避し自立過 程の早い者があると考えた。母親の自立を促す要 因については, 児の入院日数が 1 か月末満の者, 低出生体重児以外の疾病新生児, 退院時に児の看 護上の問題がなかった者などの, 児の病態や予後 に関する項目のほか, 退院時や退院後の心配・不 安がないなどが大きく影響していた。また事例検 討の結果から，ハイリスク新生児を出産した母親 に対しては, 現実認知, 社会的支援, 対処力など を考虑して, 自立を促す要因を助長するようバラ ンス保持を図るなど, 両親の親意識や役割の発達 を促すような支䍔システムが望まれる。

謝辞

稿を終えるにあたり，・調查にご協力いただきました 京都府立医科大学附属病院産婦人科岡田弘二教授, 小児科沢田淳教授に御礼申し上げます。

なお，統計解析について，ご指導をいただきました 国立公衆衛生院保健人口学部勝野真人先生に感謝 いたします。

(本論文の一部は第 4 回日本助産学会にて発表し た。)

\section{引用文献}

1) ドナC.アギュララ and ジャニスM. メズイック：小 松源助, 荒川義子訳 : 危機療法の理論と実際, 川島書 占, pp.97-103, 1978。

2) Kaplan, D. M \& Mason, E. A. : Maternal reactions to premature birth viewed as an acute emotional disorders. American Journal of Orthopsychiatry, 30 ; pp.539-547, 1965.

3) 竹内徽訳 : Marshall H. Kraus, John H. Kennell : 母 と子のきずな，医学書院，1979。 
4）竹内徽：極小未熟児における母子関係, 周産期医学, Vol. 13, No. 12, 1983。

5）小川次郎他：新生児 Special care Unitにおける母子 相互作用の臨床的心理, 行動科学的研究, 昭和 57 年度 厚生省心身障害研究「母子相互作用研究班」研究報告 書, 1983。

6）神谷育司他：新生児 Special care Unitにおける母子 相互作用, 周産期医学, Vol. 13, No. 12, 1983。

7) Susan Goldberg : Social Competence in Infancy: A model of Parent-Infant Interaction, Merrill-Palmer Quarterly, Vol. 23, No. 3, 1977.

8）中村真弓美・宮中文子：面会ノートを利用して, 日本 看愎協会近畿地区看護研究学会集録, 1984。

9）アギュララ andメズィック：前掲書。

10）桑原治雄：クライシス（危機）介入の理論と実際, 社 会精神医学, 星和書店, Vol. 9, No. 4, 別冊, 1986。

11）アギュララ and メズィッ：前掲書。

12) Kaplan, D. M \& Mason, E.A. : 前掲書。

13) Susan Goldberg：前掲書。
14）久田満, 他：ソーシャルサポートのストレス緩和効果, 日本心理学会大会論文集，第50回，p.729，1986。

15）荻須隆雄：母子保健と社会福祉資源との連携一その現 状とこれから一，母子保健情報，第14号，1987。

16）小島操子：不安を持った患者への援助の技術：患者心 理, 現代のエスプリ，至文堂，No.179，昭和57年。

\section{参考文献}

1）仁平義明，他：母親の気づいた障害児の早期の異常な 徴候に関する調查, 母性衛生, Vol. 27, No. 1, 1986。

2）仁平義明，他：母性確立への乳児の個性の影響，母性 衛生, Vol. 27, No. 4, 1986。

3）小野寺杜紀訳：Orem, D. E.：オレム看愎論, 医学書 院, 1979。

4) 大日和雅美：母性の研究, 川島書店, 1988。

5) Rapoport, Rydio.: The state of crisis; Some Theoretical Considerations, Social Service Review, Vol. 36, pp.211-217, 1962. 